\title{
A novel drug for uncomplicated malaria: targeted high throughput screening (HTS) against the type II NADH:ubiquinone oxidoreductase (PfNdh2) of Plasmodium falciparum
}

\author{
Steve A Ward ${ }^{1 *}$, Nicholas Fisher ${ }^{1}$, Alasdair Hill', Alison Mbekeani ${ }^{1}$, Alison Shone ${ }^{1}$, Gemma Nixon ${ }^{1}$, Paul Stocks ${ }^{1}$, \\ Peter Gibbons², Richard Amewu², David W Hong ${ }^{2}$, Victoria Barton², Chandra Pidathala², James Chadwick², \\ Louise Le Pensee ${ }^{2}$, Ashley Warman', Raman Sharma², Neil G Berry², Paul M O'Neill², Giancarlo A Biagini ${ }^{1}$
}

From Parasite to Prevention: Advances in the understanding of malaria Edinburgh, UK. 20-22 October 2010

The mitochondrial respiratory chain of the malaria parasite Plasmodium falciparum differs from that of its human host in that it lacks a canonical protonmotive NADH:ubiquinone oxidoreductase (Complex I), containing instead a single sub-unit, non-protonmotive Ndh2, similar to that found in plant mitochondria, fungi and some bacteria [1,2]. As such, the P. falciparum $\mathrm{Ndh}$ 2 (PfNdh2) is a potentially attractive anti-malarial chemotherapeutic target. Using an E.coli NADH dehydrogenase knockout strain (ANN0222, ndh::tet nuоB:: $n p t I-s a c R B$ ) we have developed a heterologous expression system for PfNdh2, facilitating its physicochemical and enzymological characterisation [2].

PfNdh2 represents a metabolic choke point in the respiratory chain of $P$. falciparum mitochondria and is the focus of a drug discovery programme towards the development of a novel therapy for uncomplicated malaria. Here we describe a miniaturised spectrophotometric assay for recombinant PfNdh2 (steady state $\mathrm{NADH}$ oxidation and ubiquinone reduction monitored at $340 \mathrm{~nm}$ and $283 \mathrm{~nm}$ respectively) with robust assay performance measures that has been utilised for the high throughput screening (HTS) of small molecule inhibitors.

The objectives of the HTS were twofold: (i) Increase the number of selective PfNdh2 inhibitors and (ii) to expand the number of inhibitor chemotypes. At the time of screening, only one proof of concept molecule,

'Liverpool School of Tropical Medicine, Liverpool, L3 5QA, UK

Full list of author information is available at the end of the article
1-hydroxy-2-dodecyl-4-(1H)quinolone (HDQ), was known to have PfNdh2 inhibitory activity (IC50=70 nM) $[3,4]$. HDQ was used to initiate a primary similaritybased screen of 1000 compounds from a compound collection of 750,000 compounds (curated by BiofocusDPI). Chemoinformatics methodology was applied to the hits from this initial phase in order to perform a hit expansion screen on a further $\sim 16,000$ compounds. Application of this chemoinformatic strategy allowed us to cover $\sim 16 \%$ diversity whilst screening just $\sim 2 \%$ of the compound collection.

The HTS resulted in a hit rate of $0.29 \%$ and 150 compounds were progressed for potency against PfNdh2. Of these compounds, 50 were considered active with IC50s ranging from $100 \mathrm{nM}$ to $40 \mu \mathrm{M}$. Currently seven distinct chemotypes are being progressed from hit to lead using traditional synthetic medicinal chemistry strategies.

\section{Author details}

'Liverpool School of Tropical Medicine, Liverpool, L3 5QA, UK. ²Department of Chemistry, University of Liverpool, Liverpool L69 7ZD, UK.

Published: 20 October 2010

References

1. Biagini GA, Viriyavejakul P, O'neill PM, Bray PG, Ward SA: Functional characterization and target validation of alternative complex I of Plasmodium falciparum mitochondria. Antimicrob Agents Chemother 2006, 50:1841-51.

2. Fisher N, Bray PG, Ward SA, Biagini GA: The malaria parasite type II NADH: quinone oxidoreductase: an alternative enzyme for an alternative lifestyle. Trends Parasitol 2007, 23:305-10. 
3. Saleh A, Friesen J, Baumeister S, Gross U, Bohne W: Growth inhibition of Toxoplasma gondii and Plasmodium falciparum by nanomolar concentrations of 1-hydroxy-2-dodecyl-4(1H)quinolone, a high-affinity inhibitor of alternative (type II) NADH dehydrogenases. Antimicrob Agents Chemother 2007, 51:1217-224

4. Fisher N, Warman AJ, Ward SA, Biagini GA: Chapter 17 Type II NADH: quinone oxidoreductases of Plasmodium falciparum and Mycobacterium tuberculosis kinetic and high-throughput assays. Methods Enzymol 2009, 456:303-20.

doi:10.1186/1475-2875-9-S2-114

Cite this article as: Ward et al:: A novel drug for uncomplicated malaria: targeted high throughput screening (HTS) against the type II NADH: ubiquinone oxidoreductase (PfNdh2) of Plasmodium falciparum. Malaria Journal 2010 9(Suppl 2):114.

\section{Submit your next manuscript to BioMed Central} and take full advantage of:

- Convenient online submission

- Thorough peer review

- No space constraints or color figure charges

- Immediate publication on acceptance

- Inclusion in PubMed, CAS, Scopus and Google Scholar

- Research which is freely available for redistribution

Submit your manuscript at www.biomedcentral.com/submit 